\title{
Physiology and Virulence Determinants of Neisseria gonorrhoeae Grown in Glucose-, Oxygen- or Cystine-limited Continuous Culture
}

\author{
By C. WILliAM KEEVIL, ${ }^{*}$ NICHOLAS C. MAJOR,† DAVID B. DAVIES $\ddagger$ \\ AND ANDREW ROBINSON \\ Pathogenic Microbes Research Laboratory, PHLS Centre for Applied Microbiology and \\ Research, Porton Down, Salisbury SP4 OJG, UK
}

(Received 2 May 1986; revised 8 July 1986)

\begin{abstract}
Piliated Neisseria gonorrhoeae forming small, transparent colonies $\left(\mathrm{P}^{+} \mathrm{O}^{-}\right)$on clear typing agar have been grown in prolonged continuous culture to ascertain how different growth environments might affect gonococcal physiology and the expression of virulence determinants. Virulence of the penicillin-sensitive P9-2 and the penicillin-resistant KW1 strains was assessed by their ability to survive in polypropylene chambers implanted into the flanks of guinea pigs. Initial continuous culture experiments in the defined medium of Manchee et al. (FEMS Microbiology Letters 7, 115-118, 1980) indicated that growth was actually cystine-limited, rather than the anticipated glucose-limited. Surprisingly, cysteine was not completely metabolized and ammonium salts remained in excess. The molar growth yield on glucose $\left(Y_{\mathrm{Glc}}\right)$ was $65 \mathrm{~g}$ dry wt $\mathrm{mol}^{-1}$ and $45 \%$ of the glucose carbon metabolized was converted to biomass. Gonococci, whilst retaining the $\mathrm{P}^{+} \mathrm{O}^{-}$phenotype for over 100 generations of growth, did not survive in the subcutaneous chambers when inoculated at a variety of doses. When the cystine and glucose concentrations were increased and decreased respectively, growth became glucose-limited, the $Y_{\mathrm{Glc}}$ increased to $108 \mathrm{~g} \mathrm{~mol}^{-1}$ for strain $\mathrm{KW1}$ and $75 \%$ of the metabolized glucose carbon was converted to biomass. After 17 generations of growth, however, only $2 \%$ of the gonococci retained the $\mathrm{P}^{+} \mathrm{O}^{-}$phenotype and $\mathrm{P}^{-} \mathrm{O}^{-}$bacteria predominated. Nevertheless, these bacteria were virulent in the chamber model, as was strain $\mathrm{P} 9-2$, which also retained only $2 \%$ of the $\mathrm{P}^{+} \mathrm{O}^{-}$ phenotype during glucose-limited continuous culture. By contrast, the $\mathrm{P}^{+} \mathrm{O}^{-}$phenotype was retained during prolonged cystine- or oxygen-limited growth but only the latter was virulent. SDS-PAGE of membrane extracts confirmed that opaque colonies $\left(\mathrm{O}^{+}\right)$selected from the glucose-limited cultures contained a heat-modifiable protein (protein II) whereas transparent colony types lacked such proteins. The initial phenotype of virulent gonococci recovered from the subcutaneous chambers was $\mathrm{P}^{+} \mathrm{O}^{-}$but opaque variants dominated after several days. A $40 \mathrm{kDa}$ outer-membrane protein was apparently induced during oxygen-limited continuous culture whereas a $44 \mathrm{kDa}$ protein was absent during cystine-limited growth.
\end{abstract}

\section{INTRODUCTION}

Neisseria gonorrhoeae is an obligate pathogen of man which invades columnar epithelium, for example in the urino-genital tract. In addition to causing urethritis, salpingitis and pelvic inflammatory disease, gonococci can also infect the rectum and pharynx. Blood invasion may result in arthritis, tenosynovitis or septic gonococcal dermatitis. Clearly, gonococci are versatile pathogens, capable of rapid adaptation to changes in their environment and resisting host defence mechanisms when colonizing new sites.

Clinical isolates of gonococci, when propagated on agar, grow as colonies of characteristic

† Present address: Biological Laboratory, University of Kent, Canterbury CT2 7NJ, UK.

$\ddagger$ Present address: Department of Microbiology, University of Bristol, Bristol BS8 ITD, UK. 
morphology which are predominantly types $\mathrm{T} 1$ and $\mathrm{T} 2$ and are more infectious than the less frequently isolated types T3 and T4 (Kellogg et al., 1963). The former types, in contrast to the latter, possess pili (Jephcotte et al., 1971) and these are assembled from identical subunits of a family of at least four similar polypeptides of molecular mass 18.5 to $21.5 \mathrm{kDa}$ (Lambden et al., 1981). Although these pilus types share a common antigenic region, they also possess typespecific regions and are antigenically different with respect to these sites (Virji et al., 1983). This might aid the gonococcus in evading the host defences. Similarly, colonial variation not only indicates the presence of piliated $\left(\mathrm{P}^{+}\right)$or non-piliated $\left(\mathrm{P}^{-}\right)$gonococci but also identifies opacity variants. The opacity characteristic is invariably correlated with the presence of one or more additional proteins in the outer membrane, designated proteins II, which are heat modifiable (Swanson, 1978). Opacity is related in an as yet unknown manner to the physiology of the host. Strains of gonococci isolated from infected women at the time of menstruation give rise primarily to transparent colonies $\left(\mathrm{O}^{-}\right)$, whereas isolates from women in mid-cycle give predominantly opaque colonies $\left(\mathrm{O}^{+}\right)$(James \& Swanson, 1978). The high frequency of secondary complications such as pelvic inflammatory disease observed at or near menstruation suggests that $\mathrm{O}^{-}$strains are more invasive (Holmes et al., 1976). Similarly, $\mathrm{P}^{+} \mathrm{O}^{-}$variants are more virulent than $\mathrm{P}^{+} \mathrm{O}^{+}$strains in a chick embryo model (Salit \& Gotschlich, 1978). This apparent correlation of initial infection with lack of expression of opacity proteins has also been observed using the guinea pig subcutaneous chamber model of Veale et al. (1975). Survival within the polypropylene chambers is a two-stage process, with the $\mathrm{P}^{+} \mathrm{O}^{-}$organisms predominating initially. After $3 \mathrm{~d}$, however, $\mathrm{P}^{+} \mathrm{O}^{+}$variants are selected for and maintained as the predominant phenotype (McBride et al., 1981). Interestingly, survivors contained new types of pili with subunits of molecular mass 21 and $18.5 \mathrm{kDa}$ (gamma and delta pili, respectively) rather than the original alpha and beta pili $(19.5$ and $20.5 \mathrm{kDa}$ subunit molecular mass, respectively).

Gonococcal pili are believed to be important in mediating attachment to mucosal surfaces and resistance to host defences. Similarly, proteins II have been implicated in altering resistance of the cell to complement-mediated serum killing, leucocyte association and the action of proteolytic enzymes (Heckels, 1984). Thus rapid antigenic variation in pili and proteins II might explain the ability of the gonococci to colonize and persist at anatomically distinct sites despite the host immune response. We have therefore conducted an in vitro study of the influence of a changing environment on the expression of gonococcal virulence determinants using continuous culture techniques. The chemostat allows the study of low-nutrient environments which might be encountered in the host, together with the precise control of other related parameters such as slow growth rates and $\mathrm{pH}$. Thus the chemostat may provide an environmentally-related laboratory model (a microcosm) in which in vivo-like activity of bacteria can be simulated (Bull, 1980). The nutrient restrictions investigated here which might occur in man have included the supply of glucose, essential amino acids such as cystine, and oxygen, since infections can occur in deeper-situated tissues where anaerobes are encountered.

\section{METHODS}

Strains and maintenance. Neisseria gonorrhoeae P9-2 is a well-characterized (Heckels, 1977), penicillin-sensitive strain which expresses the alpha pilus subunit; it was obtained from Dr J. E. Heckels (Southampton University). Strain KWl is a penicillinase-producing clinical isolate obtained by $\mathrm{Mr} \mathrm{K}$. A. Witt (CAMR, Porton Down). Bacteria were stored in liquid nitrogen and revived on prewarmed gonococcal clear typing agar (GCCT; Swanson, 1978) in a candle jar at $37^{\circ} \mathrm{C}$ to assess the presence of pili and proteins II. Piliation results in small, domed, highlighted (when viewed with transmitted light) colonies $\left(\mathrm{P}^{+}\right)$whilst non-piliated cells produce large, flat, nonhighlighted colonies ( $\mathrm{P}^{-}$; Jephcotte et al., 1971). The presence of proteins II creates colonies which are opaque and granular $\left(\mathrm{O}^{+}\right)$whilst their absence results in transparent colonies $\left(\mathrm{O}^{-}\right) . \mathrm{P}^{+} \mathrm{O}^{-}$gonococci were isolated for investigation.

Media and growth. The composition of the continuous culture medium was essentially that described by Manchee et al. (1980), but was modified in the light of the results obtained. The glucose-excess medium contained $\left(\mathrm{g} \mathrm{l}^{-1}\right): \mathrm{NaCl}, 5 \cdot 25 ; \mathrm{MgCl}_{2}, 0.2 ; \mathrm{NH}_{4} \mathrm{Cl}, 0.3 ; \mathrm{Na}_{2} \mathrm{SO}_{4}, 0.75 ; \mathrm{K}_{2} \mathrm{HPO}_{4}, 10.5 ; \mathrm{KH}_{2} \mathrm{PO}_{4}, 4.5 ; \mathrm{CaCl}_{2}, 0.005$; $\mathrm{Fe}\left(\mathrm{NO}_{3}\right)_{3} .9 \mathrm{H}_{2} \mathrm{O}, 0.1$; tri-sodium citrate, 1.13; L-glutamic acid, $0 \cdot 19$; L-arginine. $\mathrm{HCl}, 0 \cdot 13$; L-proline, 0.25 ; Lserine, 0.25 ; L-methionine, 0.19 ; L-isoleucine, 0.25 ; L-cysteine, 0.3 ; L-cystine, 0.025 ; glucose, 7.5 ; uracil, 0.005 ; 
hypoxanthine, 0.005 ; NAD, 0.01 ; thiamin. $\mathrm{HCl}, 0.02$; cocarboxylase, 0.02 ; biotin, 0.004 ; pyruvic acid, 1.58 ; glycerol, 1.6; sodium thioglycollate, 0.025 ; HEPES, 2.38 . The $\mathrm{pH}$ was adjusted to 7.0 with $1 \mathrm{M}-\mathrm{HCl}$ and the medium filter-sterilized through a $0.22 \mu \mathrm{m}$ Millipore filter. Glucose limitation was obtained by decreasing the glucose concentration to $1 \mathrm{~g} \mathrm{l}^{-1}$ and increasing the cystine concentration to $0.1 \mathrm{~g}^{-1}$ (see Results). Oxygen limitation was obtained by increasing the glucose concentration to $6 \mathrm{~g} \mathrm{l}^{-1}$ and decreasing the fermenter stirrer speed to 700 r.p.m.

Purified isolates were grown as lawns on GCCT for $16 \mathrm{~h}$, harvested with a loop and inoculated directly into the fermenter containing fresh medium. The growth apparatus comprised an LH Fermentation 500 series II modular fermentation system. The culture vessel had a working a volume of $500 \mathrm{ml}$ and was stirred magnetically. The dilution rate was $0.1 \mathrm{~h}^{-1}$ (equivalent to a mean generation time of $6.9 \mathrm{~h}$ ) and excess culture was removed through an overhead weir into a sterile receiver using a peristaltic pump (Watson-Marlow). Culture $\mathrm{pH}$ was maintained automatically at $7.0 \pm 0.05$ with $2 \mathrm{M}-\mathrm{NaOH}$ and was monitored with an autoclavable combination pH electrode (Russell pH). Dissolved oxygen tension in the culture was measured with a galvanic oxygen electrode (Uniprobe) and was normally maintained at $20 \%$ of air saturation by feedback control of the stirrer speed. Filtered air was introduced over the surface of the culture at $200 \mathrm{ml} \mathrm{min}^{-1}$, via the medium input port, to sweep aerosol out and prevent grow-back into the medium line. Aeration therefore occurred by vortex mixing, which minimized the frequently encountered problem of foaming of the culture and, as a consequence, did not require the use of antifoaming agents which might have affected gonococcal physiology or cell wall structure.

All parts of the fermenter with which the medium and culture would be in contact were made from glass, polypropylene or autoclavable nylon, as stainless steel has been shown to inhibit the growth of fastidious pathogens such as Bordetella pertussis and streptococci (Novotny \& Cownley, 1978; Aranha et al., 1982). To avoid the use of a stainless steel heating element in the culture, heating was achieved with an external infra-red lamp. Culture temperature was maintained at $37^{\circ} \mathrm{C}$ by a glass-sheathed platinum resistance electrode (LH Fermentation) which was immersed in the culture and was linked to the lamp via a pulse-ratio temperature control unit.

Culture monitoring. Samples were removed by suction with a syringe into sterile universal bottles via a polypropylene sampling hood. The optical density of culture samples diluted with physiological saline was measured at $540 \mathrm{~nm}$ using a Pye Unicam SP600 series 2 spectrophotometer. Biomass was assessed by rapid filtration of $10 \mathrm{ml}$ of culture through pre-dried, pre-weighed, $0.45 \mu \mathrm{m}$ cellulose nitrate (Gelman Science) or polycarbonate (Sterilin) membrane filters. The filtered samples were washed with $10 \mathrm{ml}$ distilled water and dried to constant weight in a microwave oven (approximately $3 \mathrm{~min}$ ). Estimations were done in duplicate and dry weights were calculated by differential weighing. The numbers of bacteria in the culture were determined using a Thoma counting slide with dark-ground illumination to visualize the unstained gonococci. At least 200 bacteria were counted per slide and determinations were made in triplicate.

Colonial morphology. Samples of culture were serially diluted in pre-warmed GCCT, inoculated onto GCCT agar and incubated at $37^{\circ} \mathrm{C}$ in a candle jar to determine colonial morphology and check the purity of the culture. Colonies were observed using an Olympus binocular plate microscope at magnifications of $\times 10-\times 40$ with transmitted light adjusted to show highlighting of piliated colonies. Relative percentages of each colonial type were estimated as mean values taken from triplicate plates. The results presented are the mean of at least three independent continuous culture experiments with each gonococcal strain. Error bars have been omitted from the figures for the sake of clarity but the errors were never greater than $25 \%$.

In vivo virulence determination. The method used involved inoculation of gonococci into polypropylene chambers implanted subcutaneously in the flanks of guinea pigs and subsequent sampling of the chamber for determination of viability (Veale et al., 1975; Penn et al., 1976). Briefly, small polypropylene tubes were drilled with several holes to allow the chambers to become closely associated with the host tissues without becoming vascularized. They were sealed at one end with a stainless steel staple and contained a hole in the other end through which inoculations were made. Chambers were implanted into female guinea pigs and left for $40 \mathrm{~d}$ to encapsulate before use. A $0.2 \mathrm{ml}$ sample of chamber fluid was withdrawn and plated onto blood agar $24 \mathrm{~h}$ before inoculating gonococci to ensure chamber sterility. Plates were incubated at $37^{\circ} \mathrm{C}$ both anaerobically, in an atmosphere of nitrogen/hydrogen/carbon dioxide $(80: 10: 10$, by vol.), and aerobically in a candle jar. Prior determinations of the viability of steady-state continuous cultures enabled gonococcal samples to be serially diluted in GCCT to $10^{3}-10^{6}$ viable cells ml-1, and $0.2 \mathrm{ml}$ of each was injected into the chambers. Samples $(0.2 \mathrm{ml})$ were withdrawn regularly thereafter and serially diluted in GCCT before plating onto GCCT agar for counting. The results described for each inoculum are the mean of data obtained from at least three independent continuous culture experiments with each strain, harvested and introduced into a minimum of three chambers implanted in separate animals. Cultures were considered to be virulent if they persisted in the chambers for at least three weeks, and avirulent if they persisted for less than one week.

Cell protein analysis. Samples obtained directly from the chemostat or which had been collected overnight on ice from the culture overflow were pelleted by centrifugation, and washed in phosphate-buffered saline. Cells were diluted in distilled water to a protein concentration of $2 \mathrm{mg} \mathrm{ml}^{-1}$ determined by the method of Bradford (1976). 
For the analysis of whole-cell protein, $80 \mu \mathrm{l}$ of the diluted bacterial suspension was added to $20 \mu \mathrm{l}$ of the sodium dodecyl sulphate (SDS) derivatization buffer of Laemmli (1970) and solubilized by heating at either $37^{\circ} \mathrm{C}$ for $30 \mathrm{~min}$ or $100^{\circ} \mathrm{C}$ for $5 \mathrm{~min}$. These two temperatures were used to identify heat-modifiable proteins when $50 \mu l$ of each solubilized sample was separated by polyacrylamide gel electrophoresis (Laemmli, 1970). Bacterial outer membranes were liberated by passing resuspended bacteria 20 times through a G21 gauge syringe needle prior to differential centrifugation (Zak et al., 1984). Contaminating inner-membrane material was removed by resuspending the membrane pellet in $2 \%(w / v)$ sodium $N$-lauroyl sarcosinate (Sarkosyl) and centrifuging at $100000 \mathrm{~g}$ for $1 \mathrm{~h}$ (Norquist et al., 1978). The pellet was resuspended in Sarkosyl and centrifuged again. This pellet was dissolved in derivatization buffer prior to SDS-PAGE.

Cell carbon analysis. Cultures were pelleted by centrifugation at $12000 \mathrm{~g}$ for $10 \mathrm{~min}$ and resuspended in physiological saline. This centrifugation and washing procedure was repeated. The resultant bacterial pellet was finally resuspended in freshly distilled water to minimize absorption of carbon dioxide. The carbon content of the samples was determined using a total organic carbon analyser (Beckman-RIIC Tocamaster), as described by Keevil et al. (1977).

Analytical procedures. Glucose, ammonia and amino acids in the uninoculated media, the clarified culture supernatants and uninoculated fluid withdrawn from the guinea pig subcutaneous chambers were analysed by the methods of Ellwood et al. (1974). Iron was measured by atomic absorption spectrophotometry.

\section{RESULTS}

\section{Nutrient limitation}

Neisseria gonorrhoeae KW1 grew well in the defined medium of Manchee et al. (1980) when the dissolved oxygen tension was maintained at $20 \%$ of air saturation. Higher oxygen tensions resulted in poor initial growth of inocula. Supplementing the air supply with $5 \%$ carbon dioxide had no effect on growth. Steady-state growth was achieved within 10-15 generations when the culture $\mathrm{OD}_{540}$ and cell yield ( $\mathrm{g}$ dry wt $\mathrm{l}^{-1}$ ) remained constant. The defined medium had previously been described by its users as being suitable for providing glucose-limited growth of $N$. gonorrhoeae. Surprisingly, however, glucose was found to be in excess and was detectable in culture supernatants after over 100 generations of growth (Table 1). Analysis of the nitrogen constituents of the growth medium indicated that although some of the amino acids were almost completely utilized, only cystine was absent from the culture supernatant. This was intriguing, as cysteine remained in excess. Nevertheless, cystine was confirmed to be growth limiting since halving its concentration in the medium resulted in a corresponding decrease in cell yield. In addition to the amino acids included in the medium, the gonococci appeared to produce trace amounts of alanine, glycine, histidine, leucine, threonine, valine and ornithine.

Glucose could no longer be detected in culture supernatants when its initial concentration in the medium was decreased to $17 \mathrm{mM}$. However, cystine was still not detectable and the cell yield was not significantly altered. Increasing the initial cystine concentration fourfold and decreasing the glucose concentration to $5.6 \mathrm{~mm}$ resulted in cystine, but not glucose, being detectable in the culture supernatant. The culture $\mathrm{OD}_{540}$ decreased by almost $20 \%$ but the cell yield decreased by $60 \%$ (Table 2 ).

Similar results were obtained for strain P9-2 during cystine- or glucose-limited growth (Tables 2 and 3). However, the cystine requirement of this strain was substantially less than that of $\mathrm{KWl}$ and only 0.02 mM-cystine was required to give cystine-limited growth. The P9-2 culture washed out at a dilution rate of $0.1 \mathrm{~h}^{-1}$ under cystine limitation but good growth occurred at $0.05 \mathrm{~h}^{-1}$. Oxygen limitation was obtained by incapacitating the automatic stirrer controller and maintaining the stirrer speed at 700 r.p.m. to reduce the rate of oxygen transfer into the culture. No dissolved oxygen was detectable in the culture but glucose could not be detected in the culture supernatant until its initial concentration in the inflowing medium was increased above $22 \mathrm{~mm}$. Cystine remained always in excess. Oxygen limitation resulted in the culture $\mathrm{OD}_{540}$, but not cell yield, decreasing by almost $50 \%$. Less of the amino acids, including cystine, were metabolized.

The total numbers of gonococci recovered from continuous cultures correlated with changes in culture $\mathrm{OD}_{540}$ (Table 2). Furthermore, microscopic examination showed similar cell sizes for gonococci grown under all three nutrient limitations. This suggests that the disparity between 
Table 1. Concentrations of nutrients $(\mathrm{mM})$ in unused growth medium and in supernatants obtained from guinea pig subcutaneous chambers and continuous cultures of $N$. gonorrhoeae $K W I$

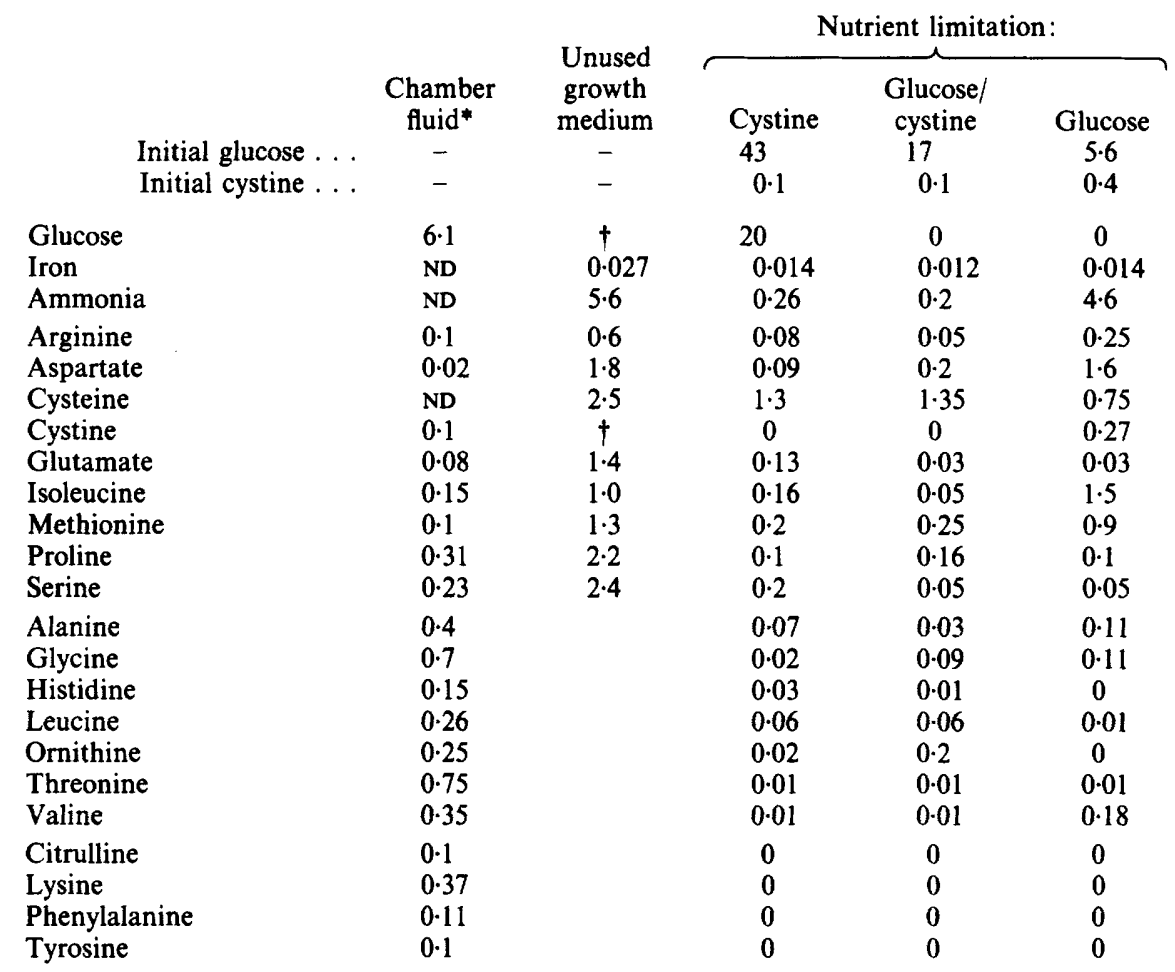

ND, Not determined.

* Concentrations described are the mean of ten chambers sampled in individual animals.

$\dagger$ These concentrations of glucose and cystine are as described in the header for the three nutrient limitations imposed.

Table 2. Concentration of bacteria, yield and glucose consumption in continuous cultures of $N$. gonorrhoeae strains $K W 1$ and P9-2

\begin{tabular}{|c|c|c|c|c|c|}
\hline \multirow[b]{2}{*}{ Nutrient limitation } & \multicolumn{2}{|c|}{ Strain KWI } & \multicolumn{3}{|c|}{ Strain P9-2 } \\
\hline & Cystine & Glucose & Cystine & Glucose & Oxygen \\
\hline $\mathrm{OD}_{5}$ & 3.05 & $2 \cdot 55$ & $2 \cdot 2$ & $2 \cdot 7$ & 1.35 \\
\hline $10^{-9} \times$ Cells ml ${ }^{-1}$ & 1.8 & $1 \cdot 3$ & 1.4 & 1.5 & 0.8 \\
\hline Yield (g dry wt $\left.1^{-1}\right)$ & 1.5 & 0.6 & 0.87 & 0.7 & 0.5 \\
\hline$Y_{\mathrm{Glc}}\left(\mathrm{g} \mathrm{mol}^{-1}\right)$ & $65 \cdot 2$ & 108 & $18 \cdot 2$ & 125 & 24 \\
\hline Biomass $(\% \mathrm{C}$ met & $45 \cdot 2$ & 75 & $12 \cdot 7$ & 86 & $16 \cdot 7$ \\
\hline$q_{\mathrm{Glc}}\left(\mathrm{mmol} \mathrm{g}^{-1} \mathrm{~h}^{-1}\right.$ & 1.5 & 0.92 & 2.75 & 0.8 & $4 \cdot 2$ \\
\hline
\end{tabular}

culture $\mathrm{OD}_{540}$ and cell yield changes was probably due to differences in the mean weight, as opposed to volume, of each cell as the gonococci adapted their physiology.

\section{Growth yield}

The yield of strain $\mathrm{KW} 1$ during cystine-limited growth was $1.5 \mathrm{~g}$ dry wt $\mathrm{l}^{-1}$ (Table 2), which was similar to that described by Manchee et al. (1980) for a different strain growing in the same medium. This corresponded to a moderately high molar growth yield on glucose $\left(Y_{\mathrm{Glc}}\right)$ of $65 \mathrm{~g} \mathrm{~mol}^{-1}$, with apparently $45 \%$ of the glucose carbon metabolized being converted to biomass. 
Table 3. Concentrations of nutrients $(m \mathrm{M})$ in supernatants obtained from continuous cultures of $N$. gonorrhoeae P9-2

The initial composition of the growth medium was as described for Table 1.

\begin{tabular}{|c|c|c|c|}
\hline \multirow[b]{2}{*}{$\begin{array}{l}\text { Initial glucose } \ldots \\
\text { Initial cystine . . }\end{array}$} & \multicolumn{3}{|c|}{ Nutrient limitation: } \\
\hline & $\begin{array}{c}\text { Cystine } \\
83 \\
0.02\end{array}$ & $\begin{array}{c}\text { Glucose } \\
5.6 \\
0.4\end{array}$ & $\begin{array}{c}\text { Oxygen } \\
34 \\
0.4\end{array}$ \\
\hline $\begin{array}{l}\text { Glucose } \\
\text { Ammonia }\end{array}$ & $\begin{array}{r}35.2 \\
3.1\end{array}$ & $\begin{array}{c}0 \\
3.9\end{array}$ & $\begin{array}{c}12 \\
2 \cdot 5\end{array}$ \\
\hline $\begin{array}{l}\text { Arginine } \\
\text { Aspartate } \\
\text { Cysteine } \\
\text { Cystine } \\
\text { Glutamate } \\
\text { Isoleucine } \\
\text { Methionine } \\
\text { Proline } \\
\text { Serine }\end{array}$ & $\begin{array}{c}0.4 \\
0.5 \\
0^{*} \\
0 \\
0.4 \\
1 \cdot 3 \\
1 \cdot 0 \\
0 \cdot 1 \\
0.1\end{array}$ & $\begin{array}{l}0.21 \\
1 \cdot 86 \\
1 \cdot 1 \\
0.36 \\
0.09 \\
1 \cdot 4 \\
0.8 \\
0.1 \\
0.1\end{array}$ & $\begin{array}{l}0.56 \\
1.8 \\
1.64 \\
0.29 \\
0.84 \\
1.7 \\
1.3 \\
1.8 \\
1.4\end{array}$ \\
\hline $\begin{array}{l}\text { Alanine } \\
\text { Glycine } \\
\text { Histidine } \\
\text { Leucine } \\
\text { Ornithine } \\
\text { Threonine } \\
\text { Valine }\end{array}$ & $\begin{array}{l}0.4 \\
0.1 \\
0.01 \\
0.1 \\
0.01 \\
0.01 \\
0\end{array}$ & $\begin{array}{l}0.04 \\
0.04 \\
0.01 \\
0.06 \\
0.01 \\
0.03 \\
0.05\end{array}$ & $\begin{array}{l}0.06 \\
0.05 \\
0.07 \\
0.01 \\
0.04 \\
0.05 \\
0.06\end{array}$ \\
\hline
\end{tabular}

The $Y_{\mathrm{Glc}}$ increased to $108 \mathrm{~g} \mathrm{~mol}^{-1}$ during glucose-limited growth and $75 \%$ of the glucose carbon metabolized was converted to biomass. Strain P9-2 grew even more efficiently than KW1 during glucose-limited growth, with a $Y_{\mathrm{Glc}}$ of $125 \mathrm{~g} \mathrm{~mol}^{-1}: 86 \%$ of the glucose carbon was converted to biomass. By contrast, the $Y_{\mathrm{Glc}}$ decreased to just $24 \mathrm{~g} \mathrm{~mol}^{-1}$ during oxygen-limited growth and only approximately $17 \%$ of the glucose carbon was converted to biomass. The cell yield and culture $\mathrm{OD}_{540}$ were relatively high during cystine-limited growth but, due to the high rate of glucose consumption, the $Y_{\mathrm{Glc}}$ was only $18.2 \mathrm{~g} \mathrm{~mol}^{-1}$ and $13 \%$ of the metabolized glucose was converted to biomass. Changes in cell yield during glucose-limited and glucose-excess growth indicated that the rates of glucose uptake by the cultures $\left(q_{\mathrm{Glc}}\right)$ varied from 0.9 to $4 \cdot 2 \mathrm{mmol} \mathrm{g}^{-1} \mathrm{~h}^{-1}$.

\section{Phenotypic variation}

When the piliated strain $\mathrm{KW} 1$ was grown cystine-limited, all of the population continued to express the $\mathrm{P}^{+} \mathrm{O}^{-}$phenotype for over 100 generations of growth. By contrast, glucose-limited growth resulted in a pronounced decrease in the numbers of piliated gonococci (Fig. 1). After 14 generations of growth (equivalent to $4 \mathrm{~d}$ in the fermenter) only $2 \%$ of the gonococci remained piliated; while the original $\mathrm{O}^{-}$phenotype predominated, spontaneous appearance of $\mathrm{O}^{+}$ variants occurred but the numbers expressing the $\mathrm{P}^{-} \mathrm{O}^{+}$phenotype did not exceed $30 \%$. Subsequently, the percentage of the culture exhibiting the $\mathrm{P}^{-} \mathrm{O}^{-}$phenotype fluctuated between 55 and $80 \%$ and $\mathrm{P}^{+} \mathrm{O}^{-}$gonococci increased their numbers again briefly before declining back to comprise only $2 \%$ of the population by 53 generations of growth. After this time, the composition of the community stabilized with over $90 \%$ expressing the $\mathrm{P}^{-} \mathrm{O}^{-}$phenotype and only $2 \%$ and $5 \%$ expressing the $\mathrm{P}^{+} \mathrm{O}^{-}$and $\mathrm{P}^{-} \mathrm{O}^{+}$phenotypes, respectively. Interestingly, $\mathrm{P}^{+} \mathrm{O}^{+}$ gonococci were only occasionally detected during the life of glucose-limited cultures which ran for over 150 generations.

Similar phenotypic variation was found with glucose-limited continuous cultures of strain P92 except that many more $\mathrm{O}^{+}$gonococci were detectable in the population. After inoculation, the 


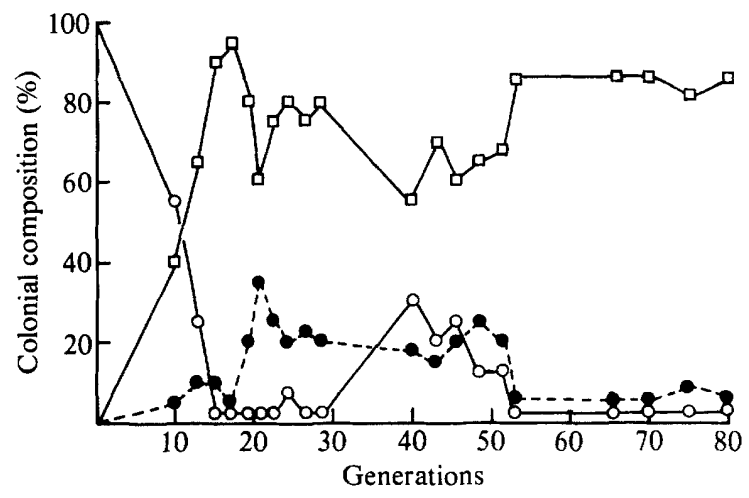

Fig. 1. Changes in the colonial composition of $N$. gonorrhoeae KW1 during prolonged glucose-limited growth. Gonococci were harvested from continuous culture and serial dilutions were plated onto GCCT agar and incubated for $24 \mathrm{~h}$ at $37^{\circ} \mathrm{C}$ to identify the $\mathrm{P}^{+} \mathrm{O}^{-}(\mathrm{O}), \mathrm{P}^{+} \mathrm{O}^{+}$(only occasionally detected), $\mathrm{P}^{-} \mathrm{O}^{-}$ $(\square)$ and $\mathrm{P}^{-} \mathrm{O}^{+}(\mathrm{O})$ phenotypes, as described in Methods.

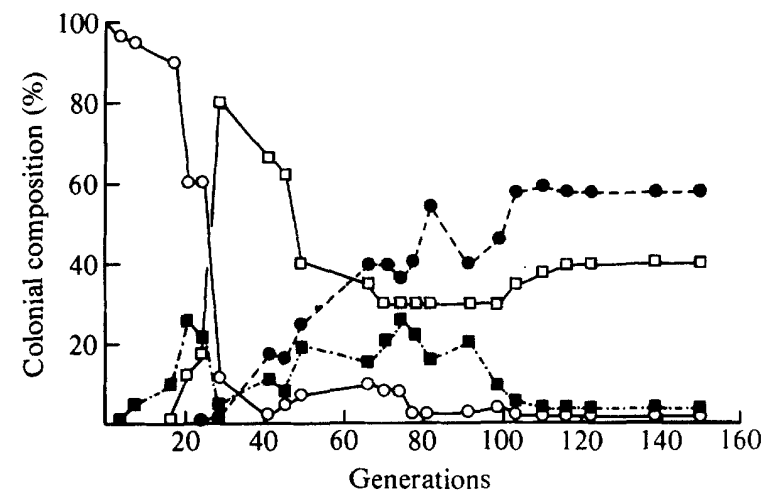

Fig. 2. Changes in the colonial composition of $N$. gonorrhoeae P9-2 during prolonged glucose-limited growth. The gonococcal phenotypes were identified as described for Fig. $1 . \mathrm{O}, \mathrm{P}^{+} \mathrm{O}^{-} ; \mathbf{G}, \mathrm{P}^{+} \mathrm{O}^{+} . \square$, $\mathrm{P}^{-} \mathrm{O}^{-} ; \mathrm{O}, \mathrm{P}^{-} \mathrm{O}^{+}$.

$\mathrm{P}^{+} \mathrm{O}^{-}$phenotype declined rapidly to comprise less than $2 \%$ of the population by 40 generations of growth and the predominant phenotype at this time was $\mathrm{P}^{-} \mathrm{O}^{-}$(Fig. 2). However, this latter phenotype also declined and was replaced by $\mathrm{P}^{+} \mathrm{O}^{+}$and, in particular, $\mathrm{P}^{-} \mathrm{O}^{+}$gonococci. The $\mathrm{P}^{+} \mathrm{O}^{+}$phenotype comprised $30 \%$ of the population by 72 generations but decreased to less than $5 \%$ by 115 generations of growth. The proportion of gonococci expressing the $\mathrm{P}^{-} \mathrm{O}^{+}$phenotype increased steadily to $60 \%$ of the population by 110 generations. This and the $\mathrm{P}^{-} \mathrm{O}^{-}$phenotype predominated thereafter.

As with the growth of cystine-limited strain $\mathrm{KW1}$, the $\mathrm{P}^{+} \mathrm{O}^{-}$phenotype of strain $\mathrm{P} 9-2$ remained stable during prolonged oxygen- or cystine-limited growth.

\section{Virulence studies}

The virulence of gonococci was assessed by incubation in the guinea pig subcutaneous chamber model (Veale et al., 1975). Samples of strain KWl were withdrawn from independent glucose-limited continuous cultures after 27 and 52 generations of growth and inoculated into the subcutaneous chambers at increasing doses. All samples remained viable in the chambers, irrespective of dosage, after $21 \mathrm{~d}$ (Table 4). Persistence of infection was not significantly affected by culture age, which determined the relatively low or high contents of piliated/opaque 
Table 4. Persistence of infection in guinea pig subcutaneous chambers of $N$. gonorrhoeae $K W l$ grown in glucose- or cystine-limited continuous culture

\begin{tabular}{|c|c|c|c|c|c|c|}
\hline \multirow{2}{*}{$\begin{array}{l}\text { Nutrient } \\
\text { limitation }\end{array}$} & \multirow{2}{*}{$\begin{array}{c}\text { Culture age } \\
\text { (generations) }\end{array}$} & \multirow{2}{*}{$\begin{array}{l}\text { Dose* } \\
\text { (c.f.u. } \\
\mathrm{ml}^{-1} \text { ) }\end{array}$} & \multicolumn{4}{|c|}{ Viable organisms $†$ recovered at day: } \\
\hline & & & 1 & 4 & 8 & 21 \\
\hline Glucose & 27 & $\begin{array}{l}10^{3} \\
10^{4} \\
10^{5} \\
10^{6}\end{array}$ & $\begin{array}{c}1.5 \pm 0.66 \\
0.78 \pm 0.43 \\
6.2 \pm 2.6 \\
4.2 \pm 2.3\end{array}$ & $\begin{array}{r}1.1 \pm 0.45 \\
0.32 \pm 0.23 \\
0.33 \pm 0.28 \\
2.0 \pm 0.93\end{array}$ & $\begin{array}{r}0.6 \pm 0.08 \\
0.59 \pm 0.24 \\
0.16 \pm 0.14 \\
0.7 \pm 0.42\end{array}$ & $\begin{array}{l}0.3 \pm 0.12 \\
0.4 \pm 0.19 \\
0.2 \pm 0.08 \\
0.4 \pm 0.21\end{array}$ \\
\hline & 52 & $\begin{array}{l}10^{3} \\
10^{4} \\
10^{5} \\
10^{6}\end{array}$ & $\begin{array}{l}1.3 \pm 0.15 \\
3.6 \pm 0.91 \\
4.2 \pm 1.0 \\
2.4 \pm 0.59\end{array}$ & $\begin{array}{l}2.4 \pm 0.65 \\
4.3 \pm 1.1 \\
7.0 \pm 2.9 \\
3.5 \pm 2.5\end{array}$ & $\begin{array}{l}2.3 \pm 0.95 \\
6.1 \pm 2.7 \\
2.8 \pm 0.62 \\
5.0 \pm 2.9\end{array}$ & $\begin{array}{r}0.4 \pm 0.22 \\
0.85 \pm 0.14 \\
0.6 \pm 0.21 \\
0.9 \pm 0.43\end{array}$ \\
\hline Cystine & 50 & $\begin{array}{l}10^{3} \\
10^{4} \\
10^{5} \\
10^{6}\end{array}$ & $\begin{array}{r}0.002 \pm 0.001 \\
0.005 \pm 0.002 \\
0.01 \pm 0.004 \\
0.03 \pm 0.016\end{array}$ & $\begin{array}{l}0 \\
0 \\
0 \\
0\end{array}$ & $\begin{array}{l}0 \\
0 \\
0 \\
0\end{array}$ & $\begin{array}{l}0 \\
0 \\
0 \\
0\end{array}$ \\
\hline
\end{tabular}

* The initial inoculum in all cases was $0.2 \mathrm{ml}$ of the reported dose.

$\dagger$ Results are expressed as $10^{-6} \times$ c.f.u. $\mathrm{ml}^{-1}$, \pm SEM.

Table 5. Persistence of infection in guinea pig subcutaneous chambers of N. gonorrhoeae P9-2 grown in glucose-, oxygen- or cystine-limited continuous culture

The initial inoculum in all cases was $0.2 \mathrm{ml}$ of approx. $1 \times 10^{6}$ bacteria $\mathrm{ml}^{-1}$. The chamber fluid was withdrawn on day 8 and plated onto GCCT agar for assessment.

$\begin{array}{ccc}\begin{array}{c}\text { Nutrient } \\ \text { limitation }\end{array} & \begin{array}{c}\text { Culture age } \\ \text { (generations) }\end{array} & \begin{array}{c}\text { Viable organisms } \\ \text { recovered* }\end{array} \\ \text { Glucose } & 27 & 0 \cdot 7 \pm 0 \cdot 44 \\ & 52 & 0 \cdot 3 \pm 0 \cdot 17 \\ & 77 & 1 \cdot 3 \pm 0 \cdot 68 \\ \text { Oxygen } & 150 & 1 \cdot 9 \pm 0 \cdot 55 \\ & 80 & 1 \cdot 6 \pm 0 \cdot 28 \\ \text { Cystine } & 125 & 5 \cdot 1 \pm 2 \cdot 4 \\ & 25 & 0 \\ & 50 & 0\end{array}$

* Results are expressed as $10^{-6} \times$ c.f.u. $\mathrm{ml}^{-1}, \pm$ SEM.

bacteria in the inocula (see Fig. 1). Cystine-limited gonococci were, however, apparently avirulent. Few viable bacteria were recovered after $24 \mathrm{~h}$ incubation in the chambers and no infection was present by $96 \mathrm{~h}$, even after the highest initial dose of $2 \times 10^{5}$ gonococci. The age of the culture also had no effect on the lack of infectivity.

Similar results were obtained for strain P9-2 (Table 5). In agreement with KW1, the numbers of viable P9-2 recovered from the chambers apparently increased as the age of the initial inocula obtained from glucose-limited continuous cultures increased. Oxygen-limited gonococci were also more virulent in the chambers as their culture age increased. By contrast, cystine-limited P9-2 was completely avirulent in the chamber model, even at an initial dose of $2 \times 10^{5}$ gonococci.

In all cases where viable $\mathrm{KW} 1$ or P9-2 were recovered from the chambers, their predominant phenotype changed to $\mathrm{P}^{+} \mathrm{O}^{+}$within $4 \mathrm{~d}$, in agreement with the observations of McBride et al. (1981). 


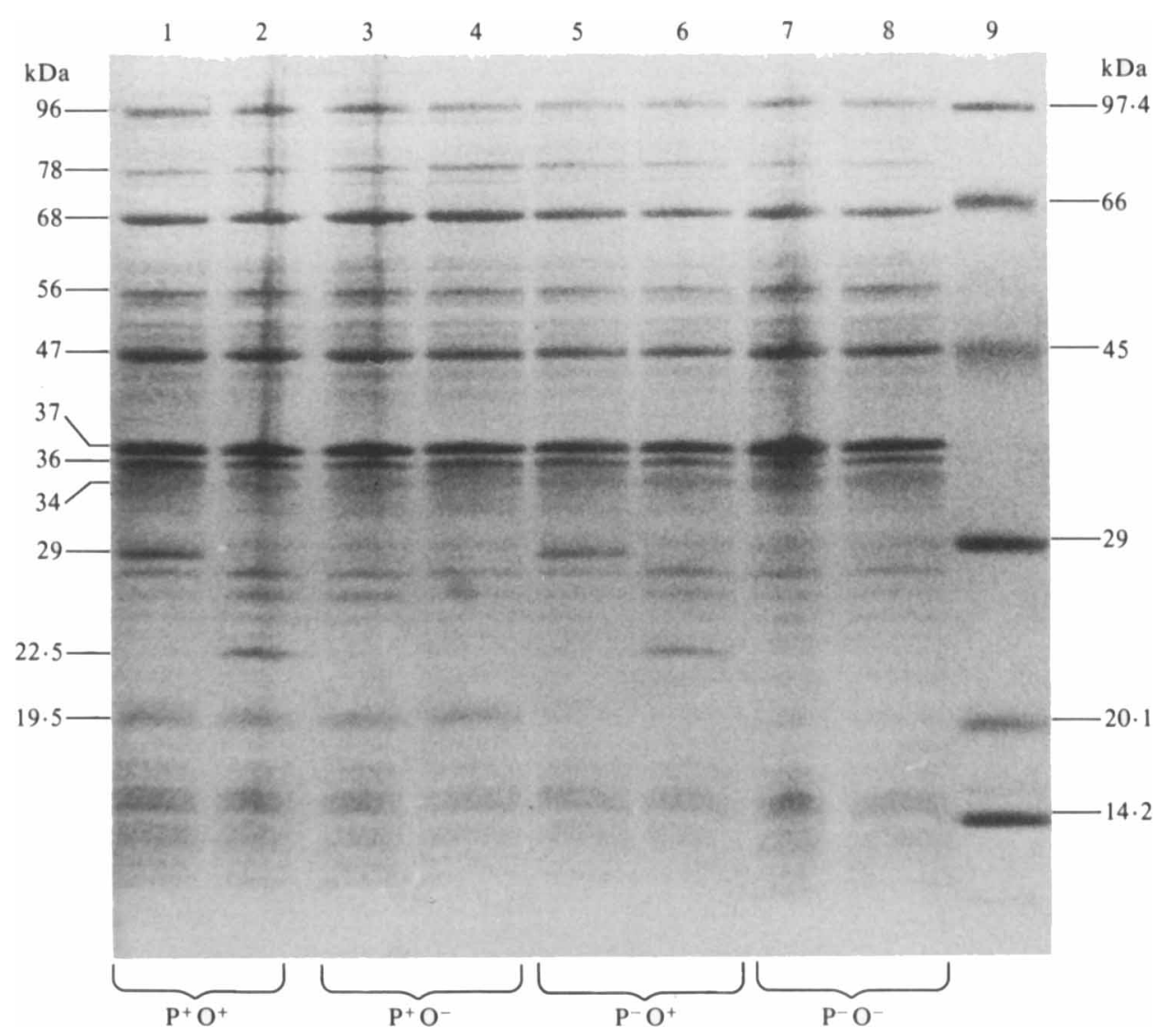

Fig. 3. Resolution by SDS-PAGE of the protein composition of whole cells of $N$. gonorrhoeae $\mathrm{KW} 1$ following prolonged glucose-limited continuous culture. Gonococci were harvested and plated out on agar as described in Fig. 1. Isolated colonies exhibiting the various $\mathrm{P} / \mathrm{O}$ phenotypes were derivatized at $37^{\circ} \mathrm{C}$ (lanes $1,3,5$ and 7) or $100^{\circ} \mathrm{C}$ (lanes 2, 4, 6 and 8), as described in Methods. Molecular mass standards are shown in lane 9.

\section{Variation in membrane protein composition}

The phenotypes of gonococci isolated on GCCT agar, after harvesting from the various continuous cultures, were confirmed by SDS-PAGE. Initially, whole-cell preparations were incubated with SDS buffer at either 37 or $100{ }^{\circ} \mathrm{C}$ to enable detection of heat-modifiable proteins II (Swanson, 1978). Fig. 3 illustrates the SDS-PAGE profiles of colonies of strain KW1 isolated from glucose-limited continuous cultures which had been growing for over 100 generations. The presence of a protein of $19.5 \mathrm{kDa}$ was apparent in the $\mathrm{P}^{+}$colonies derivatized at either 37 or $100{ }^{\circ} \mathrm{C}$ but was absent in the $\mathrm{P}^{-}$colonies. Similarly, a protein corresponding to a molecular mass of $22.5 \mathrm{kDa}$ was present in the $\mathrm{O}^{+}$colonies incubated at $37^{\circ} \mathrm{C}$ but this migrated corresponding to a molecular mass of $29 \mathrm{kDa}$ after incubation at $100^{\circ} \mathrm{C}$. Some $\mathrm{O}^{-}$isolates of gonococci have been found to contain proteins II (Heckels, 1984) but no such proteins could be detected in the $\mathrm{O}^{-}$ colonies of strain $\mathrm{KW} 1$. The major proteins present had apparent molecular masses of $96,78,68$, $56,47,37,36$ and $34 \mathrm{kDa}$, the 37 and $34 \mathrm{kDa}$ proteins probably corresponding to outer membrane proteins I and III, respectively.

Identification of the outer-membrane proteins of gonococci grown under the various nutrient limitations was attempted by resuspending bacteria in lithium acetate buffer, disrupting them in a Silverson homogenizer and obtaining membrane material by differential centrifugation 

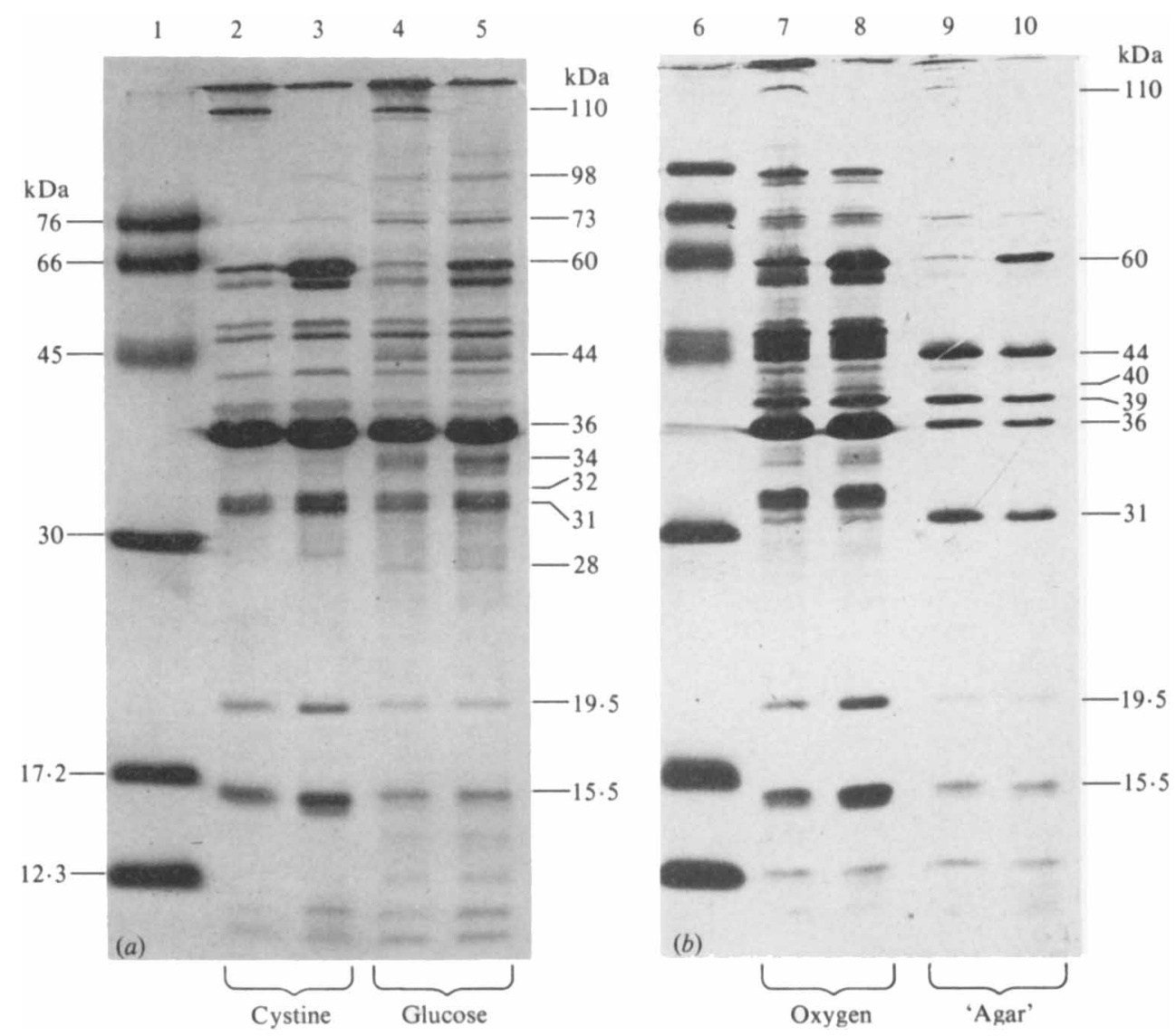

Fig. 4. Resolution by SDS-PAGE of purified outer membrane proteins of $N$. gonorrhoeae P9-2 grown in continuous culture or as colonies on agar. Gonococci were grown $(a)$ in prolonged cystine- or glucoselimited continuous culture or $(b)$ in prolonged oxygen-limited continuous culture or as $24 \mathrm{~h}$ old colonies on agar, as described in Methods. Samples were derivatized at $37^{\circ} \mathrm{C}$ (lanes $2,4,7$ and 9) or $100^{\circ} \mathrm{C}$ (lanes $3,5,8$ and 10). Molecular mass standards are shown in lanes 1 and 6 .

(Heckels, 1977). Unfortunately, this procedure did not appear to give clean preparations of outer membranes (data not shown). Similarly, liberation of outer membranes from bacteria by mild shearing through a syringe needle (Zak et al., 1984) also produced a complex number of protein bands on SDS-PAGE. The possibility that the outer membranes were contaminated with attached fragments of inner membranes was confirmed by further purification using the Sarkosyl extraction procedure of Norquist et al. (1978). This procedure produced fewer, clearly defined protein bands on SDS-PAGE (Fig. 4). The major outer-membrane protein of $N$. gonorrhoeae P9-2 grown in continuous culture, or as colonies on agar, can be clearly seen with a molecular mass of $36 \mathrm{kDa}$. The $32 \mathrm{kDa}$ protein, possibly corresponding to protein III, was also present in all gonococci grown in continuous culture but not in those grown as colonies on agar: a $31 \mathrm{kDa}$ protein was more apparent in the latter. The alpha pilus subunit $(19.5 \mathrm{kDa})$ of strain P92 appeared to be expressed during prolonged cystine-, glucose- or oxygen-limited continuous culture but, as expected, was in reduced quantity for the predominantly $\mathrm{P}^{-}$, glucose-limited gonococci. There was no evidence for heat-modifiable proteins II in the gonococcal cultures but a protein which ran with an apparent molecular mass of $110 \mathrm{kDa}$ when extracted at $37^{\circ} \mathrm{C}$ changed to a form running at $60 \mathrm{kDa}$ when extracted at $100^{\circ} \mathrm{C}$. A protein with a molecular mass of $28 \mathrm{kDa}$ was apparently induced in glucose- but not cystine- or oxygen-limited gonococci. 
Similarly, a protein of $34 \mathrm{kDa}$ was present in reduced quantity in glucose-limited strain P9-2 but was almost completely absent in gonococci grown cystine-limited. A $44 \mathrm{kDa}$ protein was present in gonococci grown on agar or in glucose- or oxygen-limited continuous culture but was absent during cystine limitation. Conversely, a $40 \mathrm{kDa}$ protein was apparently induced during oxygenlimited continuous culture but not under the other growth conditions described previously.

\section{DISCUSSION}

The present study has indicated that $N$. gonorrhoeae can be grown successfully in high yield for prolonged periods using an in vitro model system with a defined growth medium. In particular, virulent gonococci can be propagated for over 150 generations of growth when growth is glucose- or oxygen-limited. Previous workers have grown gonococci at low oxygen tensions but growth was glucose-limited rather than oxygen-limited (Leith \& Morse, 1980). Furthermore, they used a non-piliated strain which did not apparently regain piliation during continuous culture, and no mention was made of possible changes in virulence. Morse et al. (1983) have also investigated the effects of different growth rates on the lipopolysaccharide content of gonococci but, again, the only nutrient limitation investigated was glucose and the initial inoculum of bacteria was non-piliated.

By contrast, Manchee et al. (1980) are the only other workers to have investigated the continuous culture of $N$. gonorrhoeae, and they have claimed that all gonococci remain piliated under glucose limitation and that members of the culture are virulent in the guinea pig subcutaneous chamber model. The former finding is at variance with our present results since only $2 \%$ of the $\mathrm{KW} 1$ or P9-2 cultures remained piliated during prolonged glucose-limited growth. Several explanations may be advanced to account for this discrepancy. Firstly, the concentration of glucose in their initial growth medium was in sevenfold excess of the $5.6 \mathrm{~mm}$ required to provide glucose-limited growth of strains $\mathrm{KW1}$ or P9-2. Their strain might have had a high requirement for glucose, but this would appear unlikely in view of the similar yields which we obtained. Secondly, growth might have been 'glucose-depleted', some other nutrient being actually growth limiting. In support of this latter conclusion, Manchee et al. (1980) did not have an oxygen electrode present to monitor the dissolved oxygen concentration. It is possible, therefore, that growth of their strain might have been oxygen-limited, particularly at the high cell densities described for the culture. This would account for their report that all of the gonococci remained piliated and virulent in the chamber model, as we have described for our oxygen-limited gonococci.

The data obtained for the analysis of fluid obtained from sterile subcutaneous chambers (Table 1) indicated that the concentrations of glucose and cystine present were remarkably close to those employed in the present study to obtain glucose- or cystine-limited growth of $N$. gonorrhoeae. It is possible, therefore, that growth in the chambers might have been limited by either of these two nutrients. By contrast, the redox potential of sterile or infected chambers has been reported to be approximately $+260 \mathrm{mV}$ (Novotny et al., 1977). This suggests that the environment of the chambers is aerobic, irrespective of infection, and that growth is not limited by the availability of oxygen. Interestingly, only glucose-limited continuous culture gave rise to the appearance of a significant percentage of gonococci expressing the opaque colony phenotype. This result is similar to that reported by McBride et al. (1981) for the growth of strain P9 in subcutaneous chambers and which we have confirmed after inoculating this in vivo model system with strains KWI or P9-2 harvested from continuous cultures.

Although oxygen might not be limiting growth in the chamber model, it is possible that it does so in many natural infections since the potential sites of infection are colonized by facultative and fastidious anaerobes (Hurley et al., 1974). Invading gonococci must not only overcome this commensal flora to colonize the host but also grow in a presumably oxygen-limited environment (McBride et al., 1978; Young et al., 1983). The present results indicate that gonococci grow well in oxygen-limited continuous culture and retain virulence in the chamber model. Moreover, bacteria retain piliation and this characteristic has been described as an important virulence factor for the initial colonization of epithelium (Heckels, 1984). 
There is no immediate explanation as to why glucose-limited growth produces so many opacity variants whereas glucose-excess growth does not. It has been suggested that the great phenotypic and antigenic diversity of gonococci confers the ability to respond rapidly to, and thereby avoid, the host immune defence system. Recently, Virji \& Heckels (1986) have shown that possession of proteins II, previously described as 'leucocyte association proteins' (Swanson \& Heckels, 1980), allows uptake and killing by polymorphonucleocytes (PMN). Variants lacking proteins II are resistant to phagocytosis. Nevertheless, the vast majority of clinical isolates possess one or more proteins II (Zak et al., 1984). This suggests that their presence confers some essential properties, such as the ability to colonize epithelial surfaces, which are sufficiently important to the gonococcal infection to risk killing by PMN. Our results indicate that the expression of proteins II is perhaps related to the availability of glucose at potential sites of infection.

The loss of virulence of cystine-limited gonococci in the chamber model is particularly noteworthy. This appears to be related to the phenotypic expression of some essential virulence determinant, since virulence was re-established when the culture was switched from cystine- to glucose-limited growth. A similar phenotypic transition has been described for Bordetella pertussis, which can be switched from the so-called virulent $\mathrm{X}$-mode to the avirulent $\mathrm{C}$-mode and back again (Robinson et al., 1983). However, the present communication provides the first report of such a phenomenon occurring in $N$. gonorrhoeae. Interestingly, the $B$. pertussis virulence transition does not apparently involve the availability of sulphur-containing amino acids but the bacterium does metabolize cysteine rather than cystine. By contrast, our gonococcal strains, which also include an isolate harbouring the Asian $\mathrm{R}$ plasmid (unpublished data), metabolize the dimer rather than the monomer. This phenomenon was also noted by Manchee et al. (1980) for their clinical isolate of gonococcus. Presumably, certain strains of gonococci possess a specific uptake system for cystine and are unable to transport cysteine. However, we are not aware of any reports for cystine uptake although it might occur via a nonspecific dipeptide or tripeptide carrier (Payne, 1983). The availability of cysteine and cystine might be of clinical significance since the ratio of the two amino acids will be dependent on the redox potential of the site of infection. Thus aerobic sites might be considered to have a higher ratio of dimer to the monomer than more anaerobic sites.

Why cystine limitation produces gonococci which cannot survive in the chamber model is uncertain. Survival is not related to the presence of pili per se since cystine-limited gonococci retain this characteristic. Nor are there any apparent changes in production of protein I or heatmodifiable proteins II. A similar major outer-membrane protein has also been observed for the clinical isolate harbouring the Asian R plasmid (unpublished data) and this strain was identical to the previous two in unsuccessful infection of the chamber model following cystine-limited growth. Although proteins II were not induced in nutrient-limited strain P9-2 the gonococcus did contain a heat-modifiable $110 \mathrm{kDa}$ outer-membrane protein. A similar protein was also detected in strain JW-31, and Leith \& Morse (1980) concluded that it might have been an aggregate which dissociated when incubated at $100{ }^{\circ} \mathrm{C}$. However, expression of this protein was not affected by the growth environments investigated here. The only changes of note occurred in the expression of other outer-membrane proteins. For example, cystine-limited strain P9-2 lacked the 28 and $44 \mathrm{kDa}$ proteins found in glucose-limited gonococci, the latter protein also being present in gonococci grown oxygen-limited or as colonies on agar. By contrast, a $40 \mathrm{kDa}$ outermembrane protein was apparently induced in gonococci grown oxygen-limited. Interestingly, many more outer-membrane proteins were present during growth in continuous culture than as colonies on agar. Norquist et al. (1978) reported that iron-deficient growth resulted in the induction of gonococcal outer-membrane proteins. The present data indicate that other nutrient limitations also affect the outer-membrane composition of $N$. gonorrhoeae. This might not only aid gonococci in their uptake of essential nutrients, both in vivo and in vitro, but also alter their antigenic profiles and avoid the host immune response at particular sites of infection.

We are most grateful to Professor D. C. Ellwood for his encouragement during this work and to Mr K. Witt for his help with the subcutaneous chamber model. 


\section{REFERENCES}

Aranha, H., Strachan, R. C., Arcenaux, J. E. L. \& BYERS, B. R. (1982). Effect of trace metals on growth of Streptococcus mutans in a teflon chemostat. Infection and Immunity 35, 456-460.

BRADFORD, M. M. (1976). A rapid and sensitive method for the quantitation of microgram quantities of protein utilizing the principle of protein-dye binding. Analytical Biochemistry 72, 248-254.

BulL, A. T. (1980). Biodegradation: some attitudes and strategies of micro-organisms and microbiologists. In Contempory Microbial Ecology, pp. 107-136. Edited by D. C. Ellwood, J. N. Hedger, M. J. Latham, J. M. Lynch \& J. H. Slater. London: Academic Press.

Ellwood, D. C., Hunter, J. R. \& Longyear, V. M. C. (1974). Growth of Streptococcus mutans in a chemostat. Archives of Oral Biology 19, 659-664.

HeCkels, J. E. (1977). The surface properties of Neisseria gonorrhoeae. Isolation of the major components of the outer membrane. Journal of General Microbiology 99, 333--341.

HeCkELS, J. E. (1984). Molecular studies on the pathogenesis of gonorrhoea. Journal of Medical Microbiology 18, 293-307.

Holmes, K. K., Eschenbach, D. A. \& KnapP, J. S. (1976). Clinical epidemiology and changes in clinical manifestations of gonococcal infection. In Sexually Transmitted Diseases, pp. 77-83. Edited by R. D. Catterall \& C. S. Nicol. London: Academic Press.

Hurley, R., Stanley, V. C., Leask, B. G. S. \& De LouvoIS, J. (1974). Microflora of the vagina during pregnancy. In Society for Applied Bacteriology Symposium Series No. 3: The Normal Microbial Flora of Man, pp. 155-185. Edited by F. A. Skinner \& J. G. Carr.

James, J. F. \& Swanson, J. (1978). Studies on gonococcus infection. XIII. Occurrence of color/opacity colonial variants in clinical isolates. Infection and Immunity 19, 332-340.

JePhCOTte, A. E., ReYN, A. \& BIRCh-ANDERSON, A. (1971). Neisseria gonorrhoeae. III. Demonstration of presumed appendages to cells from different colony types. Acta pathologica et microbiologica scandinavica 79, 437-439.

Keevil, C. W., Hough, J. A. \& Cole, J. A. (1977). Prototrophic growth of Citrobacter freundii and the biochemical basis for its apparent growth requirements in aerated media. Journal of General Microbiology 98, 273-276.

Kellogg, D. S., Peacock, D. W., Deacon, W. E., BRown, L. \& PIRKLE, C. I. (1963). Neisseria gonorrhoeae. I. Virulence genetically linked to colonial variation. Journal of Bacteriology 83, 12741279.

LAEMMLI, U. K. (1970). Cleavage of structural proteins during the assembly of the head of bacteriophage T4. Nature, London 227, 680-685.

Lambden, P. R., Heckels, J. E., McBride, M. \& WATT, P. J. (1981). The identification and isolation of novel pilus types produced by variants of Neisseria gonorrhoeae P9 following selection in vivo. FEMS Microbiology Letters 10, 339-341.

LEITH, D. K. \& MORSE, S. A. (1980). Effect of dissolved oxygen on outer membrane protein composition of
Neisseria gonorrhoeae grown in continuous culture. FEMS Microbiology Letters 7, 191-194.

Manchee, R. J., Wiblin, C. N. \& Robinson, A. (1980). Growth of Neisseria gonorrhoeae in continuous culture. FEMS Microbiology Letters 7, 115-118.

MCBride, M. E., Duncan, W. C. \& Knox, J. M. (1978). Method for studying the role of indigenous cervical flora in colonisation by Neisseria gonorrhoeae. British Journal of Venereal Diseases 54, 386393.

MCBride, H. M., Lambden, P. R., Heckels, J. E. \& WATT, P. J. (1981). The role of outer membrane proteins in the survival of Neisseria gonorrhoeae P9 within guinea pig subcutaneous chambers. Journal of General Microbiology 126, 63-67.

Morse, S. A., Mintz, C. S., Sarafian, S. K., Bartenstein, L., Bertram, M. \& Apicella, M. A. (1983). Effect of dilution rate on lipopolysaccharide and serum resistance of Neisseria gonorrhoeae grown in continuous culture. Infection and Immunity 41, 4782.

Norquist, A., Davis, J., Norlander, L. \& Normark, S. (1978). The effect of iron starvation on the outer membrane protein composition of Neisseria gonorrhoeae. FEMS Microbiology Letters 4, 71-75.

NovotnY, P. \& CownLEY, K. (1978). Effect of growth conditions on the composition and stability of the outer membrane of Bordetella pertussis. In International Symposium on Pertussis (US Department of Health, Education and Welfare Publication no. 791830), pp. 99-123. Edited by C. R. Manclark \& J. C. Hill. Washington, DC: US Government Printing Office.

Novotny, P., Short, J. A., Hughes, H., Miler, J. J., Syrette, C., Turner, W. H., Harris, J. R. \& MaclenNan, I. P. B. (1977). Studies on the mechanism of pathogenicity of Neisseria gonorrhoeae. Journal of Medical Microbiology 10, 347-365.

PAYNe, J. W. (1983). Peptide transport in bacteria: methods, mutants and energy coupling. Biochemical Society Transactions 11, 794-798.

Penn, C. W., Sen, D., Veale, D. R., Parsons, N. J., SMITH, H. \& WITT, K. (1976). Morphological, biological and antigenic properties of Neisseria gonorrhoeae adapted to growth in guinea pig subcutaneous chambers. Journal of General Microbiology 113, 97-104.

Robinson, A., Gorringe, A. R., Irons, L. I. \& KeEvIL, C. W. (1983). Antigenic modulation of Bordetella pertussis in continuous culture. FEMS Microbiology Letters 19, 105-109.

Salit, I. E. \& Gotschlich, E. C. (1978). Gonococcal color and opacity variants: virulence for chick embryos. Infection and Immunity 22, 359-367.

SWANSON, J. (1978). Studies on gonococcus infection. XII. Colony color and opacity variants of gonococci. Infection and Immunity 19, 320-331.

SwANSON, J. \& HeCkels, J. E. (1980). Nomenclature of gonococcal outer membrane proteins, In Genetics and Immunobiology of Pathogenic Neisseria, pp. xxixxiii. Edited by D. Danielson \& S. Normark. Umeå Sweden: University of Umeå.

Veale, D. R., Smith, H., Witt, K. \& Marshall, R. B. (1975). Differential ability of colonial types of 
Neisseria gonorrhoeae to produce infection and an inflammatory response in subcutaneous perforated plastic chambers in guinea pigs and rabbits. Journal of Medical Microbiology 8, 325-335.

VIRJI, M. \& HeCKeLs, J. E. (1986). The effect of protein II and pili on the interaction of Neisseria gonorrhoeae with human polymorphonuclear leucocytes. Journal of General Microbiology 132, 503-512.

VirJi, M., Heckels, J. E. \& WaTt, P. J. (1983). Monoclonal antibodies to gonococcal pili : studies on antigenic determinants on pili from variants of strain P9. Journal of General Microbiology 129, 1965-1973.

Young, H., SARafian, S. K., Harris, A. B. \& MCMillan, A. (1983). Non-cultural detection of Neisseria gonorrhoeae in cervical and vaginal washings. Journal of Medical Microbiology 16, 183-191.

ZaK, K., Diaz, J.-L., JaCkson, D. \& Heckels, J. E. (1984). Antigenic variation during infection with Neisseria gonorrhoeae: detection of antibodies to surface proteins in sera of patients with gonorrhoea. Journal of Infectious Diseases 149, 166-173. 